\title{
MIR9-2 Pre-miRNA
}

National Cancer Institute

\section{Source}

National Cancer Institute. MIR9-2 Pre-miRNA. NCI Thesaurus. Code C82736.

MIR9-2 pre-miRNA is an oligoribonucleotide that is encoded by the human MIR9-2 gene and is involved in the regulation of gene expression. 